\title{
Contribution of Multiple Intelligence to Students' Biology Learning Outcomes in whole MAN (Madrasah Aliyah Negeri) Medan
}

\author{
Syafitri Aulia ${ }^{1}$, Herbert Sipahutar ${ }^{2}$, Syahmi Edi $^{3}$ \\ \{syafitriauliabiologi@gmail.com\} \\ Departemen Biology Universitas Negeri Medan ${ }^{1,2,3}$
}

\begin{abstract}
This research is a descriptive research with regression analysis technique at significance level $\alpha=0,05$. This study aims to determine the contribution of multiple intelligences to student biology learning outcomes in whole MAN Medan. The population in this study covers all students of class XI MIA in whole MAN Medan. The sample in this study was taken with proportionate stratified random sampling (PSRS) and simple random sampling (SRS) technique, which totaled to 281 students. The instruments of this research are multiple intelligence test and biology study result. The results obtained that multiple intelligences (multiple intelligences) contribute to student biology learning outcomes by $57.7 \%$. with the significance value of $\mathrm{X}_{1,1}=0.000, \mathrm{X}_{1,2}=$ $0.029, X_{1,3}=0.040, X_{1,4}=0.000, X_{1,5}=0.780, X_{1,6}=0.913, X_{1,7}=0.891$ and $X_{1,8}=$ 0.000 , then individually $X_{1,1}, X_{1,2}, X_{1,3}, X_{1,4}$ and $X_{1,8}$ (verbal, logic, visual, kinesthetic and natural intelligence) influence students' biology learning outcomes with significance values $<0.05$. The conclusion in this study is to see the contribution of each multiple intelligence, it can be known that what kind of multiple intelligences which has the greatest contribution or called the best predictor of students' biology learning outcomes.
\end{abstract}

Keywords: Multiple intelligences, students' biology learning outcomes

\section{Introduction}

Intelligence is the ability possessed by every human being that is closely related to human life and success (Maftuh, 2015). Intelligence is an important factor as a predictor of academic achievement in schools and has an important role in the future success of students (Kuncel et al, 2004). Zohar (2005) divides three types of intelligence, namely Intellectual intelligence (IQ), emotional intelligence (EQ) and spiritual intelligence (SQ).

There are still many educational patterns that prioritize understanding the language of intelligent students only limited to IQ. Gardner argues that linguistic abilities and logic / mathematical abilities possessed by a person do not always contribute more than other intelligences (Mahasneh, 2013). There is no certainty that students who have high intelligence will automatically succeed in learning in school (Fauzi \& Farichah, 2016).

Education has so far still and only emphasized mathematical and language logic abilities. According Purwatiningsih (2015) that the national education system that measures the level of intelligence of students who only emphasize the ability of knowledge needs to be revised, the level of children's intellectual intelligence does not only include two parameters, namely logic and language, but also must be seen from the kinesthetic, musical, visual, spatial, 
interpersonal, intrapersonal and naturalistic aspects, so that scientific development can be carried out.

An individual is said to be intelligent when the IQ test results are high (Lukman et al, 2005). So that success is solely related to intellectual intelligence because it is considered as a person's thinking capacity (Pratama et al, 2015). According to Katsis et al (2014) that high intellectual intelligence cannot show high knowledge, but a lower IQ will hamper academic performance. Academic results and IQ tests are weak predictors of true intelligence because they only measure a person's linguistic-verbal and logical-mathematical abilities (Lwin et al, 2004).

Gardner in Armstrong (2009) provides a means of mapping various abilities possessed by humans by classifying their abilities into eight intelligences or multiple intelligences. According to Al-Mahbasi et al (2017) some intelligence can produce a more interesting learning environment and support more active learning. This multiple intelligence will help teachers to recognize the strengths, weaknesses and abilities that are different from each student, so that it will help the teacher in the activities of the teaching and learning process (Koura \& Al-Hebaishi, 2014). Teachers can also help develop children's multiple intelligences by positioning children as learning centers (Komala \& Asri, 2016). Multiple intelligence approaches and assessments of learning enable students to succeed in classroom learning (Gangadevi, 2014).

Based on the results of observations made in MAN (Madrasah Aliyah Negeri) whole Medan, it was found that the teacher had applied several cooperative learning methods, although it was not necessarily appropriate for students who had different types of intelligence and were less facilitated in developing each students' intelligence. If the teacher understands multiple intelligence, they can overcome the variety of student learning styles (Richards, 2016). This is related with Murdiyanti (2012) which states that the subject matter, teaching materials, media and cognitive evaluation instruments used focus more on intellectual intelligence in the form of logic and language, whereas if the syllabus, teaching materials and media based on multiple intelligences can improve the effectiveness of biology learning outcomes. Based on the description above and in order to overcome these problems, it is important to conduct research on the contribution of multiple intelligences to the results of student biology learning outcomes in whole MAN (Madrasah Aliyah Negeri) Medan.

\section{Research Methods}

This research has been carried out in March-April 2018 at three schools of MAN (Madrasah Aliyah Negeri) Medan. The population in this study were all students of grade XI Science in MAN Medan academic year 2017/2018 as many as 942 students distributed into 21 classes (clusters) in three schools. The research sample was taken with the Proportional Stratified Random Sampling (PSRS) and Simple Random Sampling (SRS) techniques. Determination of the number of samples using the Slovin method with a total of 281 students.

The procedure of this research was carried out through 3 stages, namely: (1) the preparation phase, (2) the stage of data collection, and (3) the preparation stage of the report.

The instruments in this study include (1) direct observation when observing the teaching and learning process in class; (2) a questionnaire of multiple intelligences by Howard Gardrner obtained from the previous researcher and modified consisting of 40 statements, with a Likert scale of point 4 , where point 4 states always, point 3 states often, point 2 states 
sometimes and point 1 states never. The aspects of multiple intelligence measured include eight intelligences, namely: verbal-linguistic intelligence, logic-mathematical intelligence, visual-spatial intelligence, kinetic physical intelligence, musical intelligence, interpersonal intelligence, intrapersonal intelligence, and natural intelligence; 3) biology learning outcomes test in the form of multiple choices consisting of 25 multiple choice questions and validated in terms of content (human digestive system material) and problem construction.

Data analysis techniques include: (1) descriptive analysis, (2) quantitative analysis consisting of normality test, homogeneity test and hypothesis test of stepwise multiple regression analysis.

\section{Research Result}

The relationship between multiple intelligences (X1) on student biology learning outcomes in the form of a simple linear regression equation can be written as follows: $\hat{\mathrm{Y}}=$ $30,210+1,210(\mathrm{X} 1)$.

The correlation value is 0.760 or $76.0 \%$ which is classified as very strong. The calculated $\mathrm{F}$ value is 380.82 with a significance level of 0.000 indicating that the significance value is much smaller than 0.05 , so the regression model above can be used to see the significance of the relationship between student learning outcomes.

Contribution of multiple intelligences (X1) to student biology learning outcomes (Y) is 0.577 or $57.7 \%$, while the remaining $42.3 \%$ is determined by other variables

Table 1. Summary of Multiple Intelligence Contribution Results on Students' Biology Learning Outcomes

\begin{tabular}{|c|c|c|c|c|c|c|}
\hline No & Variable & Regression Equation & $\begin{array}{l}\text { Correlat } \\
\text { ion } \\
(\mathrm{r} / \mathrm{R})\end{array}$ & $\begin{array}{l}\text { Determin } \\
\text { ation } \\
\text { Coefficie } \\
n t\left(\mathrm{R}^{2}\right)\end{array}$ & $\mathrm{F}_{\text {count }}$ & $\begin{array}{l}\mathrm{F}_{\text {ta }} \\
\text { ble }\end{array}$ \\
\hline 1 & Multiple Intelligence $\left(\mathrm{X}_{1}\right)$ & $\begin{array}{l}\hat{Y}=-30,210+1,210 \\
\left(X_{1}\right)\end{array}$ & 0.760 & 0.577 & $\begin{array}{l}380,8 \\
2\end{array}$ & $\begin{array}{l}2 . \\
63\end{array}$ \\
\hline 2 & Verbal Intelligence $\left(\mathrm{X}_{1,1}\right)$ & $\begin{array}{l}\hat{Y}=-0.113+0.745 \\
\left(X_{1,1}\right)\end{array}$ & 0.850 & 0.722 & $\begin{array}{l}725.5 \\
33\end{array}$ & $\begin{array}{l}2 . \\
63\end{array}$ \\
\hline 3 & Logical Intelligence $\left(\mathrm{X}_{1,2}\right)$ & $\begin{array}{l}\hat{Y}=18.639+0.445 \\
\left(X_{1,2}\right)\end{array}$ & 0.505 & 0.255 & $\begin{array}{l}95.60 \\
5\end{array}$ & $\begin{array}{l}2 . \\
63\end{array}$ \\
\hline 4 & Visual Intelligence $\left(\mathrm{X}_{1,3}\right)$ & $\begin{array}{l}\hat{Y}=45.804-0.028 \\
\left(X_{1,3}\right)\end{array}$ & 0.025 & 0.001 & 0.173 & $\begin{array}{l}2 . \\
63\end{array}$ \\
\hline 5 & Musical Intelligence $\left(\mathrm{X}_{1,4}\right)$ & $\begin{array}{l}\hat{Y}=43.167+0.012 \\
\left(X_{1,4}\right)\end{array}$ & 0.012 & 0.000 & 0.042 & 63 \\
\hline 6 & $\begin{array}{l}\text { Interpersonal Intelligenceal } \\
\left(\mathrm{X}_{1,5}\right)\end{array}$ & $\begin{array}{l}\hat{Y}=39.246+0.068 \\
\left(X_{1,5}\right)\end{array}$ & 0.075 & 0.006 & 1.574 & $\begin{array}{l}2 . \\
63\end{array}$ \\
\hline 7 & $\begin{array}{l}\text { Intrapersonal Intelligence } \\
\left(\mathrm{X}_{1,6}\right)\end{array}$ & $\begin{array}{l}\hat{Y}=39.024+0.079 \\
\left(X_{1,6}\right)\end{array}$ & 0.079 & 0.006 & 1.766 & $\begin{array}{l}2 . \\
63\end{array}$ \\
\hline 8 & $\begin{array}{l}\text { Kinesthetic Intelligence } \\
\left(\mathrm{X}_{1,7}\right)\end{array}$ & $\begin{array}{l}\hat{Y}=5.099+0.676 \\
\left(X_{1,7}\right)\end{array}$ & 0.880 & 0.775 & $\begin{array}{l}961.4 \\
91\end{array}$ & $\begin{array}{l}2 . \\
63\end{array}$ \\
\hline 9 & Natural Intelligence $\left(\mathrm{X}_{1,8)}\right.$ & $\begin{array}{l}\hat{Y}=9.755+0.611 \\
\left(X_{1,8}\right)\end{array}$ & 0.775 & 0.601 & $\begin{array}{l}420.5 \\
87\end{array}$ & $\begin{array}{l}2 . \\
63 \\
\end{array}$ \\
\hline
\end{tabular}


Multiple intelligence (X1) consists of several components of intelligence, namely verbal, logical, visual, musical, interpersonal, intrapersonal, kinesthetic and natural intelligence. The contribution of each intelligence is; verbal intelligence (X1.1) contributes 0.722 or $72.2 \%$, logical intelligence $(\mathrm{X} 1.2)$ contributes 0.505 or $50.5 \%$, visual intelligence (X1.3) contributes 0.001 or $0.1 \%$, musical intelligence $(\mathrm{X} 1,4)$ contribute 0,000 or $0 \%$, interpersonal intelligence $(\mathrm{X} 1,5)$ contribute 0,006 or $0,6 \%$, intrapersonal intelligence $(\mathrm{X} 1,6) 0,006$ or $0,6 \%$, kinesthetic intelligence $(\mathrm{X} 1,7)$ contribute 0,775 or $77,5 \%$ and natural intelligence (X1.8) contribute 0.601 or $60.1 \%$. (Table 4.1 ).

Based on the significance value that is $\mathrm{X} 1,1=0,000, \mathrm{X} 1,2=0.000, \mathrm{X} 1,3=0.678, \mathrm{X} 1,4=$ $0.838, \mathrm{X} 1,5=0.211, \mathrm{X} 1,6=0.185, \mathrm{X} 1.7=0.000$ and X1.8 $=0.000$, then individually X1, $\mathrm{X} 1,2, \mathrm{X} 1,7$, and $\mathrm{X} 1,8$ (verbal intelligence, logic intelligence, kinesthetic intelligence and natural intelligence) contribute each component to students' biological learning outcomes with a significance value of $<0,05$. While other variables do not contribute to each component of emotional intelligence with a significance value of $>0.05$.

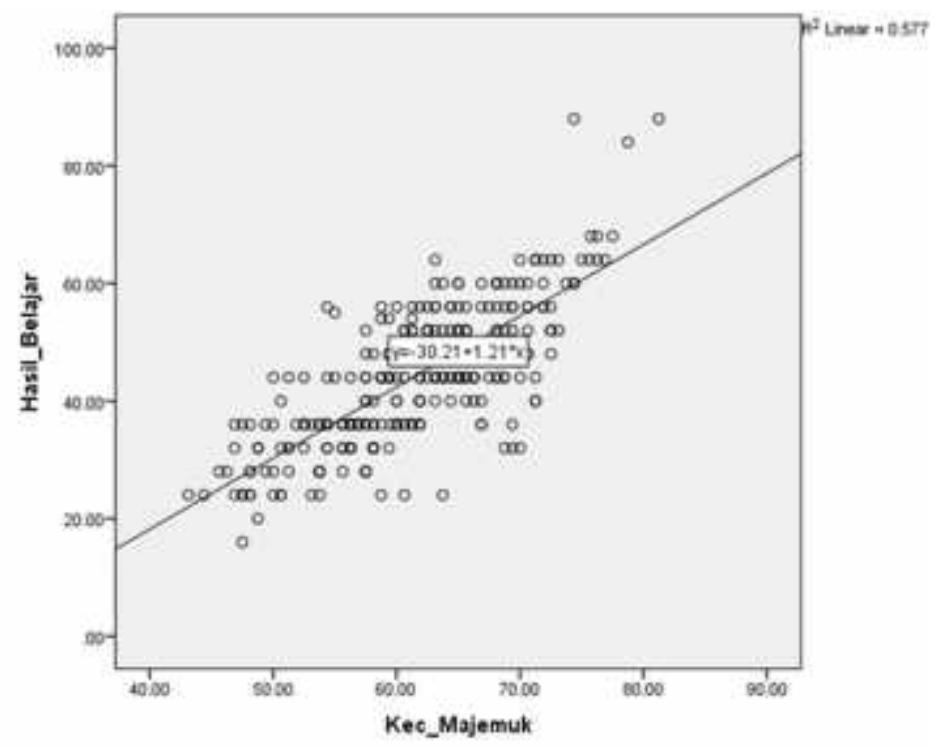

Fig. 1. Contribution of Compound Intelligence with Student Learning Outcomes

\section{Discussion}

Based on the results of the study, it is found that multiple intelligences can simultaneously predict the students' biology learning outcomes. In this case multiple intelligences that have individual contributions from each component of intelligence to students' biology learning outcomes are language, logic, kinesthetic and natural intelligence.

Verbal intelligence has a contribution of 0.722 or $72.2 \%$, this intelligence has an important meaning in achieving optimal learning outcomes, where verbal intelligence is the ability of a person to think of a series of available words. This intelligence is an important intelligence in all academic and non-academic activities in secondary schools. Verbal intelligence reveals 
how well a person can understand ideas expressed through words (verbal), and how clearly one can think and reason with words. With verbal intelligence students will more easily understand the biological science concepts provided by the teacher (Solihah, 2012).

Logical intelligence has a contribution of 0.255 or $25.5 \%$, logical intelligence also has a contribution in achieving student biology learning outcomes, where logical intelligence is the intelligence to recognize thought patterns of a logical relationship and concepts. According to Gardner (1989) if someone has this logical intelligence then the skills that will be possessed are scientists and mathematicians, because biology is a science subject, so it is necessary to contribute logical intelligence to the biology learning outcomes.

Kinesthetic intelligence has a contribution of 0.775 or $77.5 \%$, kinesthetic intelligence possessed by students is quite high because in biology learning experiment is often carried out which makes students more active in moving when practicing. This is in line with Bire (2014) that students who have kinesthetic intelligence in which students will immediately take action in learning so that the process and learning outcomes become more smooth and maximal. Kinesthetic intelligence also enhances creative learning so that students become aware of lessons that grow toward student achievement (Uzho \& Salame, 2016).

Natural intelligence has a contribution of 0.601 or $60.1 \%$, natural intelligence possessed by students also includes predictors of students' biology learning outcomes, this is because biology learning does not escape nature. Visits to nature or learning directly from nature can increase students' knowledge. This is related with Lesmana (2016) which states that natural intelligence / naturalist can improve science learning outcomes which have implications in everyday life. It is said that natural intelligence is because this intelligence is a person's ability to recognize and classify species such as flora, fauna and the environment and also includes sensitivity to other natural phenomena, so that this intelligence has links with science which includes biological subjects.

Each intelligence has its own advantages, so that none of the students is considered superior to others (Morgan, 2004). Intelligences that contributes to students' biology learning outcomes are language, logic, kinesthetic and natural intelligence, but that does not mean that other intelligences are considered not superior, this is why Gardner classifies their abilities into eight intelligences or multiple intelligences rather than looking at their IQ level (verbal and logic) only but by looking at the potential of verbal, logical, visual, musical, interpersonal, intrapersonal, kinesthetic and natural intelligence.

Gardner in Armstrong (2009) provides a means of mapping various abilities possessed by humans by classifying their abilities into eight intelligences or multiple intelligences. This level of intelligence can develop or can even be hampered along with increasing age and influencing factors, the strong weakness of each multiple intelligence is influenced by biological factors, life history, personal, cultural and historical backgrounds. Multiple intelligence can help teachers to recognize the strengths, weaknesses and abilities that are different from each student, so that it will help teachers in the activities of the teaching and learning process (Koura \& Al-Hebaishi, 2014). The ability of teachers to recognize multiple intelligences possessed by students is very important, this factor will be very decisive in planning the learning process that must be taken by students (Murray, 2012).

The development of multiple intelligences theories and with their acceptance in the world of education, this theory can be applied in the class. Multiple intelligences learning is learning that values the intelligence possessed by students, and a variety of ways of learning students (Samsinar, 2014) and provides opportunities for students to use a type of intelligence that is prominent in encouraging learning (Spirovska, 2013). According to Amalia (2015) that a dominant intelligence potential can develop optimally if the potential possessed by the child is 
designed in the right and continuous way through a fun and varied way in learning. One way that can be done is with multiple intelligences-based learning, this is related with Andini's (2018) research that the application of learning based on multiple intelligences can stimulate the diversity of intelligence possessed by students and make the learning atmosphere more enjoyable.

\section{Conclusion}

Based on the results of research and discussion, it can be concluded that the contribution of multiple intelligences to the students' biology learning outcomes in grade XI Science in whole MAN (Madrasah Aliyah Negeri) Medan is 0.577 or $57.7 \%$, while the remaining $42.3 \%$ is determined by other variables. By looking at the contribution of each component of multiple intelligences, it can be known which components of multiple intelligences have the greatest contribution or are called thebest predictors of student biology learning outcomes.

Acknowledgments. Thank you for my thesis supervisors, Mr. Prof. Dr. Herbert Sipahutar, M.S., M.Sc. and Mr. Dr. Syahmi Edi, M.Si., who helped me a lot in completing this article and the MAN (Madrasah Aliyah Negeri) schools in Medan that helped me a lot in collecting data for the completion of this article.

\section{References}

[1] Al-Mahbasi, A. A., Noor, N. M \& Amir, Z, The Effect Of Multiple Intelligences on DDL Vocabulary Learning,(International Journal of Applied Linguistics and English Literature, ), pp.182191.( 2017)

[2] Amalia, F. R, Pengembangan Multiple Intelligences Siswa Oleh Guru Melalui Kegiatan Pembelajaran Pendidikan Agama Islam. Skripsi, UIN Sunan Kali Jaga, Yogyakarta, (2015).

[3] Andini, Y, Effect Of Application of Multiple Intelligences Multiple Learning Models to Mathematical Learning Results. (Prosiding Diskusi Panel,), pp.1-8. (2014)

[4] Armstrong, T, 2009,Multiple Intelligences in The Classroom $3^{\text {rd }}$ Edition, USA : ASCD.

Bire A, L. \& Bire, J, Pengaruh Gaya Belajar Visual, Auditorial, Dan Kinestetik Terhadap PrestasiBelajar Siswa, (Jurnal Kependidikan,) pp. 158 - 174. , (2014)

[5] Fauzi, A and Farichah, E,The Implementation of Multiple Intelligences on Learning Process at SMP IT and SD IT Madani Islamic School of Cilegon Banten Province Indonesia,(International of Journal Home Science, Banten Indonesia,),pp. 50-57. (2016)

[6] Gangadevi, R, Multiple Intelligence Based Curriculum To Enhance Inclusive Education To Bring Out Human Potential, (International Journal of Advanced Research,) pp. 619-626.( 2016)

[7] Gardner, H. \& Hatch, T, Multiple Intelligences Go To School: Educational Implications Of The Theory Of Multiple Intelligences, (Journal American Educational Research Assosiation,) pp. 4-10.( 1989)

[8] Komala \& Asri, C, Efektivitas Program Pembelajaran Dengan Menggunakan Permainan Tradisional Untuk Mengembangkan Kecerdasan Majemuk Anak Usia Dini. (Jurnal Ilmiah UPT P2M STKIP Siliwangi,) pp. 1-8. (2016)

[9] Kotsis, A., Kiss, M \& Kun, A. I, The Relationship Between Intelligence, Emotional Intelligence, Personality Styles and Academic Success, (Journal Business Education \& Accreditation,) pp. 23-34. (2014)

[10] Koura, A.A \& Al-Hebaishi, M, The Relationship Between Multiple Intelligences, Self Efficacy And Academic Achievement of Saudi Gifted And Regular Intermediated Students, (Journal Educational Research International,) pp. 48-70.( 2014) 
[11] Kuncel, N. R., Hazlet, S. A and Ones, D. S, Academic Performance, Career Potential, Creativity, and Job Performance: Can One Construct Predict Them All?, (Journal of Personality and Social Psychology,), pp. 148-161.( 2004)

[12]Lesmana, F. 2016. Pengaruh Kecerdasan Naturalis terhadap Hasil Belajar IPA Materi Tumbuhan dan Hewan di Al-Khoiriyah 2 Semarang. Skripsi, FTIK, UIN Walisongo : Semarang.

[13]Lukman, A and Patahuddin,Hubungan Intelegensi Jamak (Multiple Intelligences) Dengan Hasil Belajar Ekonomi Akuntansi Ranah Kognitif Siswa SMA Negeri 1 Watan Soppeng, (Jurnal Penelitian dan Evaluasi Pendidikan,), pp. 1-9.( 2005)

[14]Lwin, M, Khoo, A, Lyen, K \& Sim, C. 2004,How to Multiply Your Child's Intelligence : (Pener. Christine Sujana) (Cara Mengembangkan Berbagai Komponen Kecerdasan). Indonesia : PT. Indeks

[15]Maftuh,IntelegensiSebagaiFaktorBelajar, (Jurnal MIYAH,) pp. 168-179.( 2015)

[16]Mahasneh, A.M,The Relationship Between Multiple Intelligence And Self Efficacy Among Sample of Hasemithe University Students, (International Journal of Education and Research,), pp. 11-12.( 2013)

[17]Morgan, J.A \& Carmen, F, Multiple Intelligences Theory And Foreign Language Learning : A Brain-Based Perspective, (International Journal of English Studies,) pp. 119-136.( 2004)

[18]Murdiyani, I, Pembelajaran Biologi Menggunakan Metode E-Learning Berbasis Multiple Intelligences Pada Materi Sistem Gerak Manusia. (Innovative Journal of Curriculum and Educational Technologi,) pp. 45-52.( 2012)

[19]Murray, S \& Kylie, M, Inclusion Trough Multiple Intelligences, (Journal of Student Engagement: Education Matters, ) pp. : 42-48.( 2012)

[20]Pratama, A. T., Syamsuri, I, Adi, and Aloysius, D. C, The Contribution of Intelligence Quotient (IQ) on Biology Academic Achievement of Senior High School Students In Medan, Indonesia (International Journal of Educational Policy Research and Review,) pp.141-147.( 2015)

[21]Purwatiningsih, "Pembelajaran Biologi Berbasis Multiple Intelegensi Berpendekatan Observation Based Learning”, Prosiding Seminar Nasional Pendidikan Biologi 2015,FKIP Univ. Muhammadiyah Malang, 2015.

[22]Richards, The Integration Of The Multiple Intelligence Theory Into The Early Childhood Curriculum, (American Journal of Educational Research,) pp. 1096-1099.( 2016)

[23]Samsinar, Korelasi Strategi Multiple Intelligences Dengan Kualitas Pembelajaran Pendidikan Agama Islam Pada SMPN Di Watampone, (Jurnal Lentera Pendidikan,)pp. 58-71. (2014)

[24]Sholiha, I., Karyanto, P., Sugiharto, B, Kekuatan Dan Arah Kemampuan Metakognisi, Kecerdasan Verbal, Dan Kecerdasan Interpersonal Hubungan Dengan Hasil Belajar Biologi Siswa Kelas XI IPA SMA Negeri 3 Sukoharjo.(Jurnal Pendidikan Biologi,) pp. 31-39.( 2012)

[25]Spirovska, E, Integrating Multiple Intelligences In Teaching English As A Foreign Language-Seeu Experiences And Practices,(Journal Versitas,)pp. 1-12.( 2013)

[26]Uzho \& Salame. 2014. Use of Bodily-Kinesthetic Intelligence Theory to Improve the Creative Learning of the English Language in Students of $1^{\text {st }}$ EGB at Undidad Educativa Bilingue Instituto Particular Abdon Caderon. Research Project, Educativa Bilingue Instituto Particular Abdon Caderon : Ecuador.

[27]Zohar, D,Spiritual Intelligent Leadership. No.38,2005,ocw.knu.edu.tw/sysdata/doc/0/0615c5ca0e84309a/pdf.pd,(28 September 2017). 